\title{
Public Space and Social Polarization. A case study of the New Wave Turkish Migrants with a comparative analysis of Berlin, İstanbul \& Ankara
}

\author{
Ceren Kulkul \\ Humboldt University of Berlin, Germany \\ Berlin Graduate School of Social Sciences \\ cerenkulkul@gmail.com
}

\begin{abstract}
Public space is by no means a place for complete unity or harmony. It is always open to contradiction and struggle. It is a space in which dwellers of the city find various ways to cope with living with one another. This could be in the form of negotiation, or confrontation. Or, it could be where they avoid others, where they maintain distance. Yet, there is always the expectation of all parties, to have one's own place in that struggle. Turkey has experienced increased social polarization in recent years, and this is reflected in its public spaces. With the 'us' versus 'them' mentality in politics being also found in everyday urban life, the gap between different lifestyles has greatened, hostility among people has intensified and urban space became a battlefield rather than a ground for commons. Hate and intolerance began to define what is public. In the meantime, a great number of high-skilled, young individuals, particularly from İstanbul and Ankara, began to leave the country to carve out a better future; and, one of the popular destinations was Berlin, Germany. This paper addresses this group of young migrants to make a comparative analysis on the definitions of public space and to rethink the social production of urban space. With thirty interviews and two focus groups, it aims to consider the reflections of social polarization on public space.
\end{abstract}

Keywords: public space, social production of space, urban, youth, migration

To cite this article:

Kulkul, C. (2020). Public Space and Social Polarization. A case study of the New Wave Turkish Migrants with a comparative analysis of Berlin, İstanbul \& Ankara, The Journal of Public Space, 5(I), III-I28, DOI I0.3289I/jps.v5il.II28

This article has been double blind peer reviewed and accepted for publication in The Journal of Public Space. (c) This work is licensed under a Creative Commons Attribution - Non Commercial 4.0 International License https://creativecommons.org/licenses/by-nc/4.0/ 


\section{Prologue}

In 2013, during the Gezi Park protests, an anonymous manifesto was published addressing the demands of people from different social groups saying that "I am here, because I don't want to be told how to dress; what to eat or drink; how to make love; and how many children to have. I don't want to be insulted due to my lifestyle or choices. I want to be able to express my thoughts freely, even though they may sound nonsense to others. I don't want to be discriminated against due to my religion, my religious sect, my ethnicity, my sex or my social stature. If I am unhappy with something, I want to be able to freely walk into the public arena and loudly say "No!".",

On June $18^{\text {th }}, 2016$, a group of ten to fifteen people attacked a vinyl shop, called Velvet Indieground Records, in Beyoğlu Firuzağa during an event for the famous British Rock Group Radiohead. A section from the news on that day reported that "the reason for the attack was alcohol consumption". One attacker yelled, "Shut this place down, now! Aren't you ashamed of drinking during Ramadan" while another one threatened people "I will burn you while you're inside. Try drinking during Ramadan again and you'll see what will happen."2

\section{Introduction}

In recent years, Turkey has faced several socio-political crises and conflicts. These were especially brought to light through the Gezi uprising in $2013^{3}$, the numerous terror attacks and coup attempt in 2016, and the referendum for a presidential government in 2017. This tension regards mostly lifestyles, beliefs, life choices and preferences. But all are eventually linked with civil rights and liberties. Social arena witnessed conflicts among secular and religious perspectives. As an element of these debates, life choices became a highly controversial topic. Discussions about abortion ${ }^{4}$, use of alcohol, sexual preferences, and even the visibility of pregnant women ${ }^{5}$ are spoken about.

Once a dominant view on these issues begins to be spoken about and imposed in the media medium and in the public realm, groups of people who have a different worldview begin to dissent to said societal assertiveness. The more dominant the imposition is, the tenser the opposition becomes. It has not only been politicians who have got involved in these rough in debates, but also people without political backgrounds have started to keenly argue about their life choices. Some groups advocate the ideals and opinions of the government which have been mostly grounded by either religious codes or conservative points of view ${ }^{6}$. However, some others (not necessarily supporters of the opposition parties) rejected the externally imposed ideals and norms regarding personal matters, choices and lifestyles ${ }^{7}$. Through the increasing polarization between the religious versus the secular, one political party versus another, one sect versus another, and one life view versus another, people in Turkey eventually found themselves in a very strict 'us' versus 'them' situation. Even by a mere observation on the streets, one can easily trace how frequently people mention this separation, just by noting the 'us' and 'them' in an idle conversation, even though it is usually difficult to find a concrete and explicit defined 'other' party. Obviously, this polarization did not emerge in one day or as the result of a single event. The notion of difference became more and more visible between various perspectives and lifestyles over the years. Eventually, the public sphere became more under dispute day by day. 
Cities are no longer like the agoras of Ancient Greece. They are crowded, multifaceted, complicated and contested. Acts, interactions, encounters are not facile or smooth. Any practice in public space appears as an act of claiming a right over that place. Consider 'occupy' movements, protests against discrimination or pride marches. However, claim of public space does not solely appear in the form of a concrete resistance. Sometimes it reveals itself in small acts of everyday life. Through such ingrained practices, urban space is socially produced. But the question of this paper is: if there is high sociopolitical polarization within a society, then how will public space be? Beyond the natural complexity of urban space, this question uncloaks a deeper tension.

These past few years have not only born witness to harsh conflicts in the public arena. Today, Turkey is also under the risk of facing the negative consequences of brain drain. A great number of highly skilled young professionals and students are in pursuit of leaving Turkey and to continue their lives in other countries (Yörükoğlu \& Kaya, 2017: $3 \mathrm{I})$. This paper, on the basis of their comparative experiences in İstanbul, Ankara and Berlin, investigates the ways of defining urban spaces with respect to accessibility, inhabitability, the feeling of security and freedom, and sharing commons. This paper neither makes any generalizations about public space use nor builds a naïve understanding of city life. The only aim it seeks is to reconsider the meaning of public space, particularly in times of political turmoil and social segregation. It anticipates being an empirical contribution to existing public space literature.

\section{Research Design and Methodology}

The best way of understanding what people think about their own experiences is to let them speak about their opinions and practices. So, the research for this study was conducted based on qualitative research techniques; in-depth interviews and focus groups. Without any attempts to be representative in terms of the sample, thirty indepth interviews were conducted and two focus groups were organized with a composition of five to six participants. Interviews consisted of three main parts: migration experiences, public space use (comparatively), and social networking in everyday urban life. Focus groups, on the other hand, were mostly about the feeling of freedom, security, claiming rights over a city and the consequences of social polarization in Turkey.

\section{Understanding the Sample}

The sample was selected intentionally from a recently migrated group in order to gain deliberate and comparative knowledge on all cities within the study. This group of young, highly skilled individuals was not homogenous in terms of the reasons for their migration. However, all interviewees can be considered as migrants and have had experience on both sides. At the time of the interviews all interviewees lived in Berlin, but they previously lived either in İstanbul or Ankara, for amount of considerable time. In the social sphere, this group is called the New Wave, because there was a former massive migration to German cities in the 1960s as a result of work recruitment from Turkey by Germany. New Wave refers to a second wave of migration and it was originally a Facebook group which was created for cooperation and socialization among 
Turkish newcomers to Berlin. Since this name was used so frequently among participants, the group is referred to as being a part of the New Wave in this paper as well.

Migration is a transformative practice and it is by no means an easy experience. Before addressing the main questions of this paper, there is need to understand the daily lives of the New Wave and their experiences in the public sphere. According to the participants, the main difficulties involve: language, isolation and the chances of establishing roots in Germany.

In the interviews, the most frequently mentioned difficulty was language. As Berlin provides numerous English-speaking opportunities in education and the labor market, coming to Berlin seems relatively easy to many people. However, without compatibility in German, many young individuals experience difficulties finding jobs or being permanent residents in Germany. The lack of knowledge of German even reveals itself in public life despite the fact that Berlin is one of the European cities in which use of the English language is rife. A respondent expressed that "I felt myself voiceless before I learned German, in those times, feeling in that way made me lose my motivation towards participating in social life in Germany."

The second difficulty reported was the feeling of loneliness. It was repeatedly mentioned that this is due to a lack of close relationships and the inability to get along with others. A female respondent, a 25 -year-old, stated this feeling of isolation as "It is not because I don't have friends here. It is nothing to do with social relations either. You can't be really close with your friends here. There is always a context in which you see each other and certain topics that you talk about. It never goes beyond this context." One reason for such feelings may be that the participants were recent migrants to Berlin, with no long establishments in the city.

Finally, regarding the chances of establishing roots in Germany, only a few interview partners said that they are totally fine with going back to Turkey after their educational studies are completed. The majority of answers about returning to Turkey are either rigorously rejected, or accepted only as a worst case scenario. Therefore, managing to somehow establish roots in Europe comes into prominence in their future plans. But that is also a challenge. A respondent expressed that, "At first, it was all good in Berlin. But as time passes and as I try to make a life here, it is getting tough, especially in terms of finding a job." but still continued by saying, "But, I mean, still, my most miserable day in Berlin this year is still much better than my best day back in Turkey, in 2016." So, anxiety about their future plans continues in a different manner for them as they think of being at ease in comparison to how they previously felt in Turkey. The preference is still Berlin.

\section{Understanding the Setting}

Germany vastly became one of the targets of immigration firstly because it encourages the migration of educated groups in industrial, technological and scientific areas of work and it aims to generate employment in the business sector ${ }^{8}$. Berlin is favored for its relatively cheaper living conditions, its wider range of educational and occupational opportunities and its vibrant social life. It has attracted a great number of educated, highly skilled young professionals, academics and artists from Turkey as well. Moreover, existing Turkish culture in German cities provides the potential for opportunities for 
Turkish people that come to Germany either by social networks (relatives or acquaintances who have lived here and are established) or by the deep-seated Turkish society and culture. Although it does not appear as a reason to migrate, it eventually makes the city attractive?.

İstanbul, on the other hand, by being the largest and most crowded city of Turkey, offers various educational and occupational opportunities in comparison to other cities in the country. However, it also demands great effort to build a life and to make use of public spaces. Due to its traffic problem and dense population, the use of time and space can rarely be efficient. It is a capital of culture on one hand, but a chaotic urban order on the other. Especially in the last decade, the urban fabric of the city has drastically changed because of new construction projects in the area. İstanbul is a city in which the aforesaid polarization and conflict are experienced the most. This is because a great variety of distinct social groups and lifestyles are involved. The characteristics of this huge crowded city are surely innumerable, but for the purposes of this research, the reason for selecting İstanbul is due to the background of the participants. Either as a hometown or as the city where they attended university (and in some cases where they also worked for a while), respondents were asked to compare İstanbul to Berlin. Ankara, as the last city within this study, is different from İstanbul. It is the capital of Turkey and for the most part it revolves around affairs of the state. It is usually described as 'city of civil servants' by people to define its mediocrity. Among thirteen interviewees, four of them came to Ankara for higher education and the rest remarked that Ankara is both their hometown and the city in which they continued their higher education. This indicates that despite its well-known universities, in comparison to İstanbul, Ankara is less likely to be a preference for many respondents to study if they are not already living there. Regarding the space use of Ankara, unlike İstanbul or Berlin, it has a relatively uncomplicated urban life. Nevertheless, socio-spatial segregation is higher due to the larger areas allowing for the creation of suburbs which in turn enlarges the distance between socio-economic groups.

\section{Social Production of Public Space}

Cities are produced, not only by urban planning, but also by their dwellers, each day with each practice in public space. Jane Jacobs argued that urban planning should not dominate urban space since social life exists in the sharing of commons, using spaces, and encounters; and these are particularly what generate a social life of mutuality, tolerance and togetherness (Jacobs, 196I). Taking into consideration the three cities within this study, Ankara, İstanbul and Berlin, all have a particular way of being socially produced. As this paper argues, in Turkey, this social production is highly based on socio-spatial segregation, particularly in recent years. In the light of the interviews conducted, the most frequently mentioned characteristics of these cities and the ways of using urban public spaces are analysed to understand the consequences of this segregation more clearly.

"Ever since its birth, public space has acted as a central social and political arena in which free expressions of ideas and opinions are allowed and encouraged." (Qian, 2018: 13). For example, Arendt (1958) referred to the Greek agora to describe an ideal case of publicity. Habermas also argued that 'only in the light of the public sphere did that 
which existed become revealed, did everything become visible to all." (Habermas, 1989: 4) However, unlike Arendt or Habermas, who saw commonality and harmony in public space, Judit Bodnar described public space as "the clearest expression of the urban predicament, the tension between the physical proximity and moral remoteness of city dwellers." (Bodnar, 2015: 209I). The predicament and tension is not necessarily an actual battle of dwellers, but may appear sometimes as the strategy of negation or the ignoring of others.

In this paper, both views are acknowledged and it is argued that urban life is a unity of conflict and harmony. Thus, all three cities will be approached according to their perceived levels of harmony or tension. In the analysis, the important concerns are about free access to urban places, the visibility of differences in urban environments, the feeling of security for everyone, and on the basis of all these, the possibility of sharing commons in the city. These are the fundamental topics of how "public space" was defined by interview participants.

\section{The Case of Ankara}

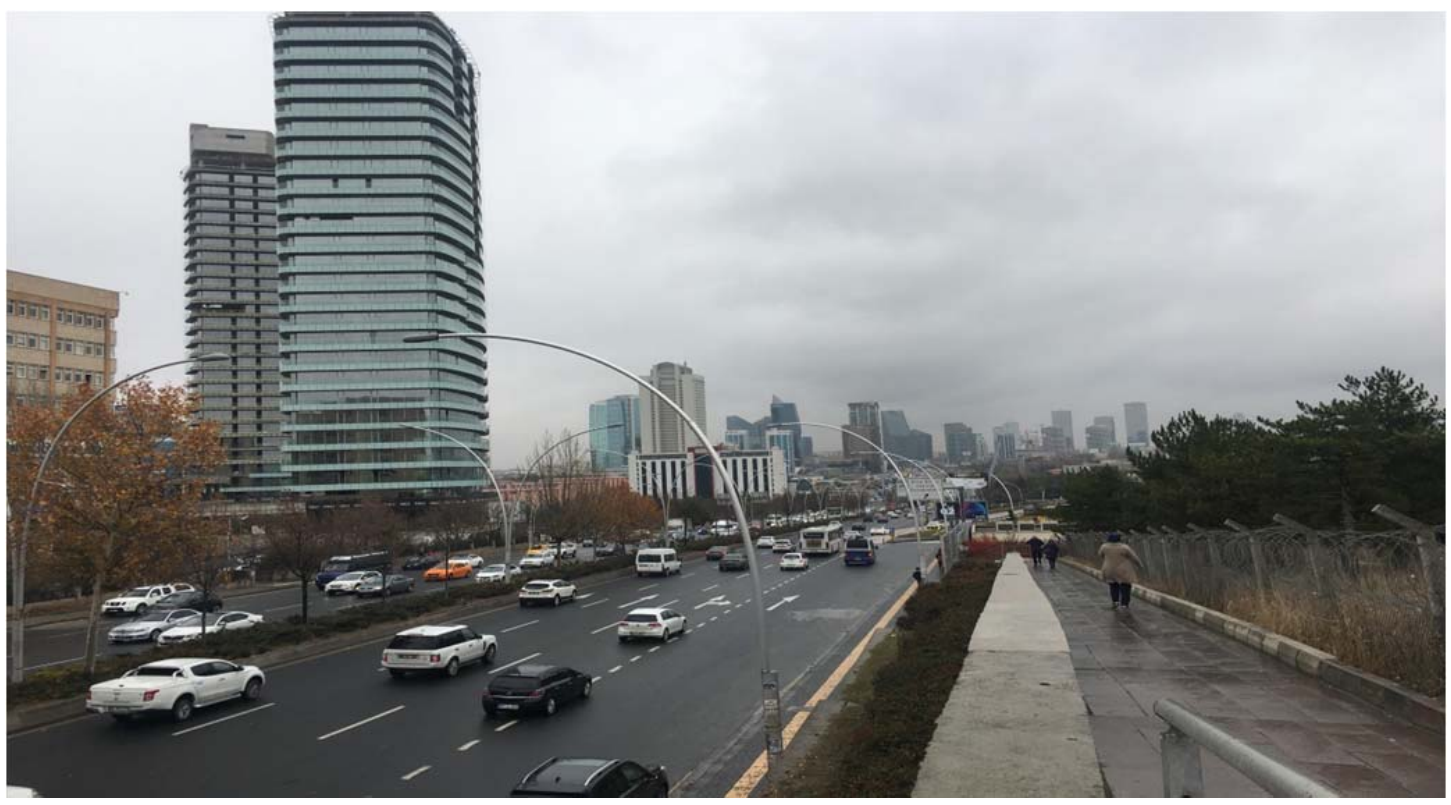

Figure I. Eskișehir Road in Ankara (December 2019) 10

Sennett defined public space as 'dead' (Sennett 2013: 27), where the conflict is transformed to distance between social classes and public space turns out to be an abandoned place. Ankara is a good example of this upper-middle class disengagement from the rest of the city; whereas, in İstanbul and in Berlin social segregation does not appear through spatial distance. In Ankara, it is created with huge boulevards between boroughs, widening the urban setting beyond edges. Some suburb areas like Çayyolu or Yasamkent have emerged in the last decade with the desire of the upper-middle class for detachment". The suburbanization is a visible feature of social production in this city and it strengthens the polarization not by conflict -because there is little interaction- but 
with spatial distance. Public space is jeopardized of rupture when there is a huge spatial gap compounded by an existing social polarization among different groups. Although suburbanization is understandably seen as a result of social class mobility, under the circumstances of high political polarization, it could also be analysed as a result of sociopolitical conjuncture.

Neighbourhoods like Çayyolu, Yașamkent, and Ümitköy are considered to be the dwelling of 'secular', highly skilled, well-educated, upper-middle class families. Whether this statement is correct or not is not the topic of this study. However, this perception was visible in the interviews. For example a 24-year-old interviewee explained that "I was living with my parents in Çayyolu before coming here. But I wasn't only residing there. I was spending most of my time there with friends and family. I find Çayyolu as a place of my own. There is a standard of people, you know, it is a liberated area." This emphasis on it being a liberated zone was also mentioned by other respondents regarding Çankaya -an inner city district of Ankara- and for the Kadıköy District of İstanbul. These statements carry strong meaning as they refer to a strict distinction of political views. However, there was no clear expression of from what, or from whom, these places were seen as liberated.

The inner city has also been under considerable change through urban transformation. While speaking of public spaces in Ankara, an interviewee mentioned that the only place she could ever live in Ankara is the Çankaya District. According to a recent research study, Çankaya is the most educated district of Turkey as it also includes the university campuses of Middle East Technical University and Bilkent University ${ }^{12}$. She particularly emphasized this information while saying that she somehow identifies herself with the area.

According to the interviews, the most prominent characteristic of public space in Ankara is the absence of open areas. In other words, public space is described by its deficiencies. A respondent laughingly said that, "I wasn't aware of these constraints in Ankara, before I moved to Berlin. I didn't ever think about it while I was living there." The constraints she refers to are mainly the lack of "open areas to spend time in". Another interviewee mentioned the same problem in Ankara, "There are malls everywhere. If you don't have a car, you can't even go somewhere for fresh air. There are roads, shopping malls, other roads, and then more shopping malls." Similar to other responses, Ankara is defined as a city of enclosure. This enclosure is sometimes based on a transportation and access issue; at other times it is related with social polarization. A respondent clearly expressed the latter reason by saying, "In Turkey we were living seriously confined. It was often a discomfort. For instance, when I was about to go somewhere, I needed to think through which areas I would pass. If I would go through one neighbourhood than it would be better to wear these jeans, but not a skirt." The consideration she gave to clothing is not a choice she made herself but rather a preemptive solution to any possible confrontation -a gaze, maybe even a disturbing word. This kind of example was also given by other respondents, and it can be seen that public space in Turkey are very likely to be based on this discomfort, of changing oneself for others.

Parallel to a feeling of discomfort, insecurity in the public arena emerges as an important dimension of city life. Especially among women, the feeling of security is frequently mentioned as a luxury in public spaces of Ankara and İstanbul. A respondent from 
Ankara said that, "It is even absurd to mention how uncomfortable and insecure I was when I lived in Turkey. Even a short walk alone down the street at night was an issue." According to the interviewees, being a woman in Turkey appears as a challenge and it requires conceiving time and space all the time. For example, an interviewee spoke about her public space experiences in the city center of Ankara, saying that she always had to consider what time it was and where she was at that moment; "If you are a woman, you live according to time and space. If it is late at night you should take a cab, not walk... if you are on a busy street at night it is fine to walk, if it is a desolate place, you should find your way out." The feeling of security is also tied to being familiar with a place. For instance, people usually feel more safe and comfortable in the neighborhood they have lived in for many years. However, gender dimension goes further and exceeds familiarity. A female respondent said that, "I spent time in Tunalı for almost a decade, since I was a teenager; I know every inch of the area. I didn't even think about my safety there. But, it is not because I was safe, rather because I already knew how to secure myself. It is something that I built on my own." Therefore, the feeling of safety does not come from the public space or social environment per se. It is rather recognized and developed through various strategies of women themselves. How this situation has changed after they moved to Berlin will be explained later.

To sum up, Ankara remained insufficient for many respondents to fulfill their expectations about public space. Most prominently, the lack of open areas, the lack of public transportation and the feeling of insecurity were mentioned as the main characteristics of the city. But more importantly, almost all interviewees from Ankara mentioned that they were not fully aware of the enclosure and restrictions they had faced in Ankara until they moved to Berlin.

\section{The Case of İstanbul}

As interviews revealed, social life in İstanbul is formed according to districts as the city is too large and transportation is difficult. Many interviewees emphasized that they only used specific boroughs in the city. These are; namely, Kadıköy, Beșiktaș, and Beyoğlu. There is nothing surprising in the localization of inhabitants in specific districts; whereas, it is worth seeing how the concentration of specific groups determines the urban fabric in those public spaces. Kadıköy is considered to have the most hipster public in İstanbul. There is a locality which originated, mostly, from a boulevard name, but nowadays it is considered as if it is a neighborhood, called Moda, and it has undergone massive gentrification in the few last years. Secondly, Beșiktaș is one of the biggest and oldest districts of İstanbul. It has historical significance dating back to the Byzantine and Ottoman empires, but it also has contemporary importance for transportation, social life and business. The well-known neighbourhoods of the European side of İstanbul; namely, Etiler, Bebek, Levent, Arnavutköy, Nișantașı and Ortaköy, are located under the Beșiktaș municipality and district ${ }^{13}$. Beyoğlu is another district which has the neighbourhood of Cihangir which has functioned for many years after a gentrification process as a safe locality for intellectuals, artists and bohemia. 


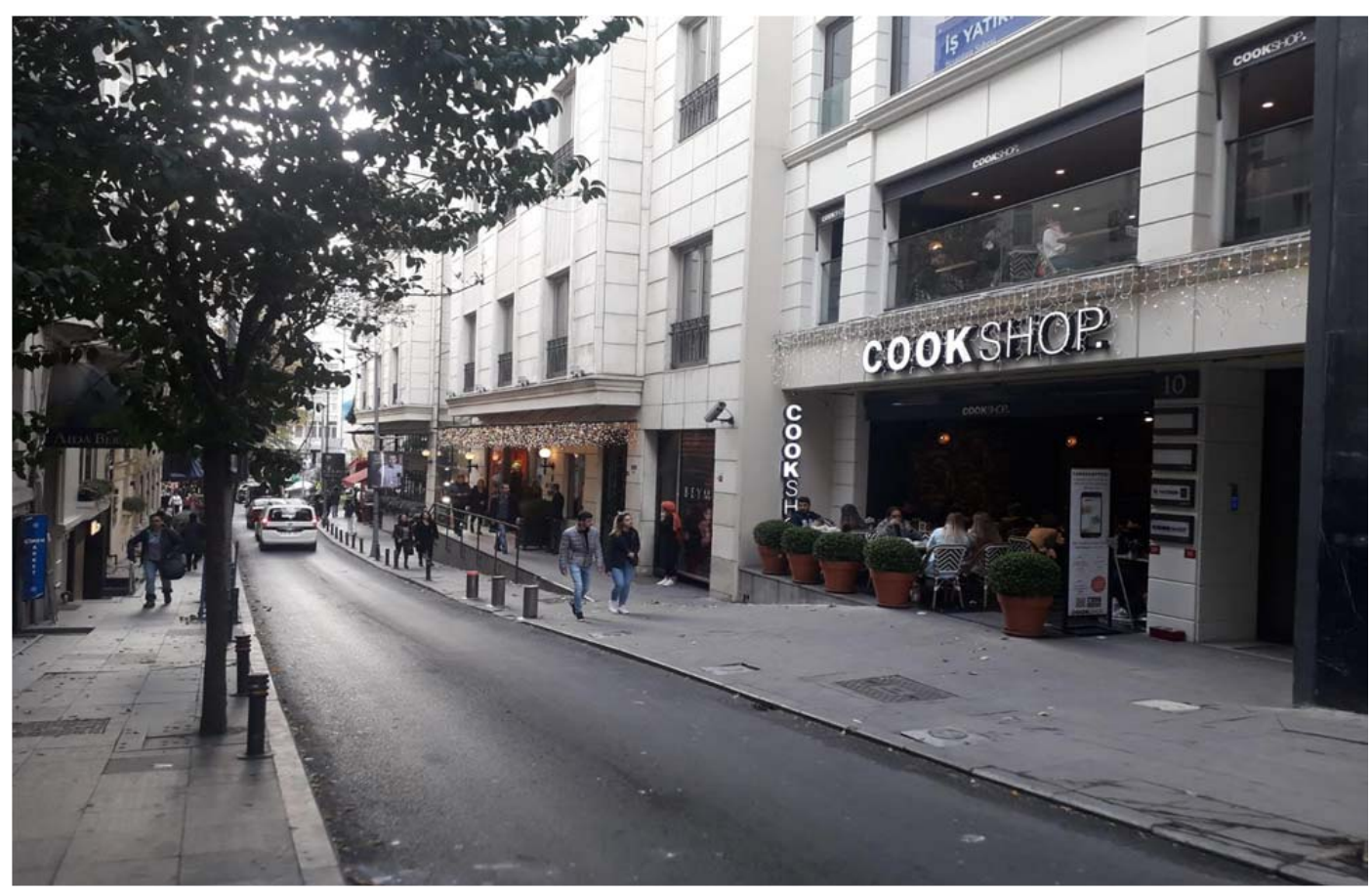

Figure I. A street view from Nișantașı - an upper-middle class neighborhood (December 2019)

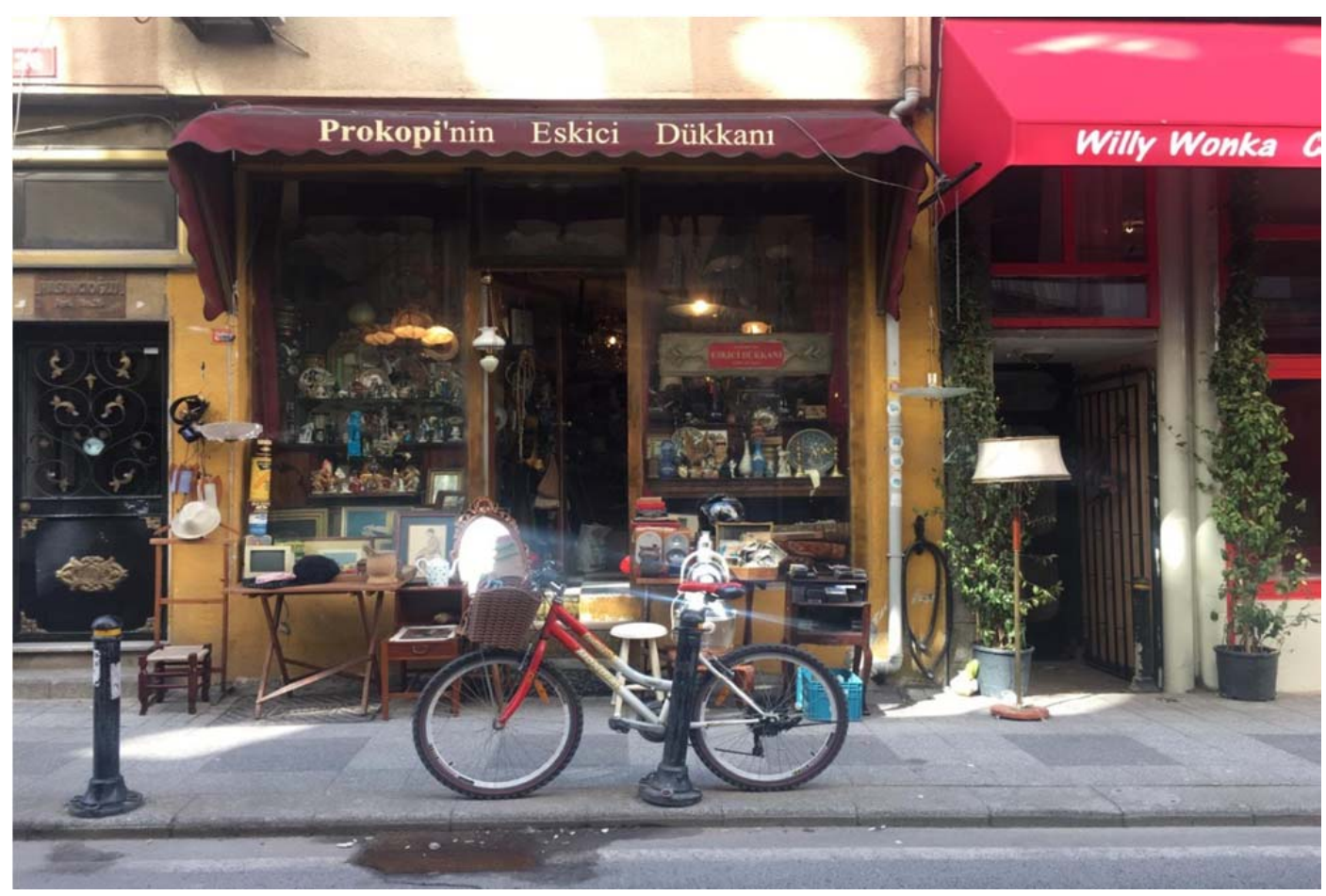

Figure 2. A vintage store in a gentrified area around Kadıköy, Moda (March 2019)

Most respondents from İstanbul mentioned that they were using İstiklal Avenue and Beyoğlu as the meeting point of their circle of friends. Then, they all added, "But those 
places have changed, so radically changed." When I asked one interviewee to explain this change, she told me, "Well, you can't find people like us anymore. Even if you could, there is a majority that you could never interact with. I can't even recognize those places, places where I spent the entirety of my teenage years." Yet another interviewee stated, "Not only people, but, I mean... The venues have changed. Maybe this is something that we see only because we used to spend all of our time in İstiklal, Beyoğlu, and Taksim. It is ugly now. Somehow, it is not for me anymore. I can't explain how, but I can feel it." Such expressions give the very importance of being an inhabitant of a city that one cannot verbalize but surely feel, especially the change. Also, the expressions of 'people like us' and 'cannot even recognize now' show the very ingrained feature of social segregation and disappointment. In the expression of 'people like us' the identity of the other 'people' is never crystal clear and only a few respondents were willing to depict the other. As for many other respondents, when I asked them to open it up, answers were similar to this one: "You name them... Say it government supporters, say right-wing, conservative, religious -but I mean not really pious people, who have nothing to do with politics" The 'other' is thus never specified in an explicit way but all respondents spoke about 'them' as if we all know who they are. Secondly, for the feeling of disappointment that is indicated in many interviews with 'cannot find anything suitable for me anymore' or 'cannot recognize the place', it is highly related with a discomfort of 'others' prevailing in the public space. A 25 -year-old interviewee made a conspicuous expression; "In last two years, and especially with that coup attempt, we realized that the city does not only belong to us... that the city has other owners as well." As it is visible in this statement, public space is conceived as a place to own, to occupy and to fight for, against 'others'; and for İstiklal and Taksim, it is believed that the battle over public space possession was lost.

With the change experienced in most preferred localities of the European side, many people, including some interviewees, crossed over to the Anatolian side, to Kadıköy. It is not certain whether it was the moving of people that created a new urban life there or that the desired cafés and bars no longer found in Taksim, already existed there before the move. Either way, the change in Kadıköy brought gentrification, bohemianism and social transformation.

Kadıköy has always been one of the localities similar to Beșiktaș or Beyoğlu. However, over the last few years, as many interviewees mentioned, Kadıköy became almost the only locality for their lifestyle. A respondent said that, "Kadıköy is a rising trend. I used live there before moving here (referring Berlin). It has changed very fast. Everywhere, there is a third wave coffee shop, a local venue, a hipster bar..." and another one described her neighbourhood, Kadıköy, as: "It is a place where people don't ever intervene with one another. It is modern. It has people with high incomes. It is where even stray cats are fed, -which, to me, is a sign of social status. " Therefore, Kadıköy is more than a preferred district; it is a symbol of a secular and a modern way of living. On the other hand, some other districts such as Beylikdüzü, Fatih, and Ümraniye are mostly mentioned as unfavourable places to go, to spend time at, or to reside in. These areas are again identified with a non-specific other. In other words, interviewees commonly referred to others in the sense of political view as well as social lifestyle and religious belief; however, they never clearly expressed who the other was.

Nevertheless, the connotations of such urban areas are strongly linked with the notion of other which eventually creates an unwillingness to go there. Although it requires 
further analysis to claim that spatial segregation is a strategy for city-dwellers of the city to prevent the encounter with the others; the vague reference of interviewees still indicates a two-sided society. It is not to say that there are only two groups in the city; it is rather the perception of the New Wave about Turkish society.

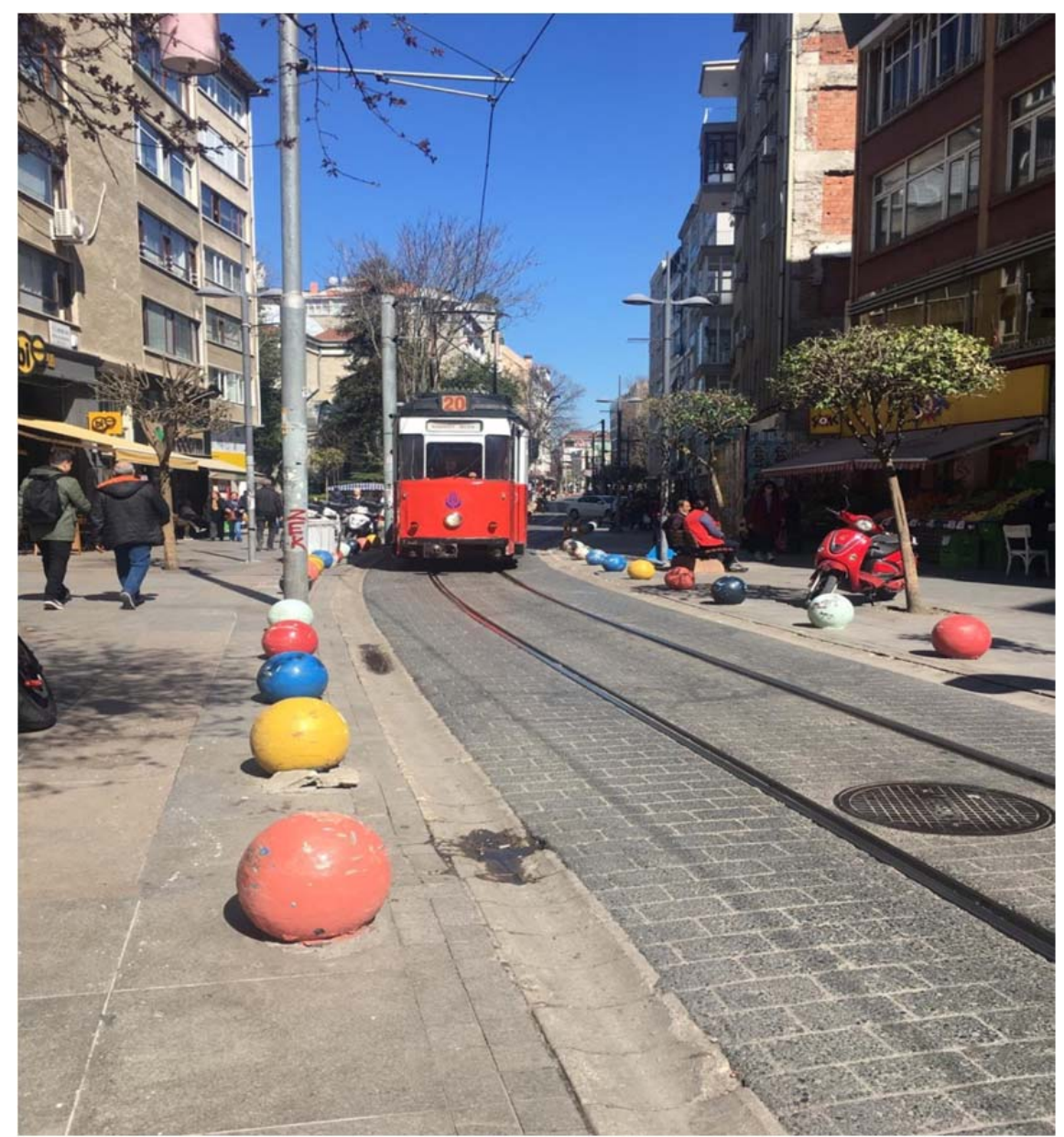

Figure 3. A street view from Bahariye, Kadıköy (March, 2019)

To sum up, the first set of districts is composed of neighbourhoods that are appealing for the high-income group, and many interviewees argued that these are 'secular' places. This notion of secularity is not necessarily used in contrast to religiosity. As it was explained by respondents frequently, it is to say that they feel more comfortable with their attire, actions, behaviour and accessibility as there are coffee shops, hipster bars, trendy restaurants and rapid gentrification in these locations. The second set of boroughs, on the other hand, is described as the total opposite of the former; being relatively conservative and not having any attraction for interviewees of this study. A very common usage of the phrases "What would be the reason for me to go those areas?", "Why would I ever go there?" was observed in the interviews. The implication of other also reveals itself here, once again with very vague definition. 
The notion of security was also a frequently mentioned topic among interviewees from İstanbul. Having the same issues in public space as a woman just as in Ankara, respondents from İstanbul also spoke about the freedom of choice as a part of feeling secure. A 25-year-old male respondent mentioned security with a deliberate awareness of his own identity in terms of gender by saying; "Look at me; a man, a heterosexual, a person who grew up in Güngören, İstanbul... I had never really experienced nor understood the feminist movement until my ex-girlfriend from Croatia came and stayed in my parent's house. We couldn't use $95 \%$ of the city without having trouble. In the end, I spent all of my money at an air-bnb in Beșiktaș to be comfortable."

Although he complained about this situation, he later added that, "Putting up a fight for all identities adds beauty to social life." However for many other respondents, especially those who fought that battle for their sexual identities, the struggle is tiring most of the time. A respondent who identified as queer said that, "Knowing that I wouldn't be attacked by someone for holding hands with my boyfriend is something I value in Berlin." and he succinctly summarized the problems he had previously faced in Turkey by saying that, "In Turkey, my life choices are considered to be a psychosexual disorder." The feeling of security is not necessarily about gender identity, but in this research study it appears to be the most prominent feature of those seeking safety and freedom. In order to feel free in public space, people need to feel safe with their life choices and identities. Ankara and İstanbul do not provide this sense of security or freedom to the interviewees, and while in Berlin they realized just how restricted they had previously been. This will be analysed later on.

\section{The Case of Berlin}

In Berlin, both suburbanization and borough separation exist, but socio-spatial disengagement is relatively low in comparison to the former cities discussed. Unlike Ankara, Berlin has an extensive subway and railway line which allows for more frequent everyday encounters among different social groups. Even if not upper class, the middle class surely coexists with all city dwellers and a great variety of lifestyles have contact with each other. Unlike İstanbul, Berlin is considered to be largely constructed by its inhabitants. An interviewee said that, "Everywhere is public space in Berlin. It's for the people, really... I have got used to it. Every place is somehow occupied by people. Parks, bridges, everywhere is open to us. In İstanbul, you only have small places like this." For İstanbul, public space is mostly seen as a place of restriction. A strong control mechanism functions as a key to be comfortable and free of judgement. A respondent stated that, "You can't speak your own language (emphasizing a mindset, knowledge) everywhere in İstanbul. You must be quiet in some places." As regions and localities are highly identified with the generalized mentality of its population ${ }^{14}$, public space is directly related with free speech and free actions.

The most striking finding about the public spaces of Berlin for the New Wave is the shift in perception towards others and differences. It was already said that respondents claimed that they would never go to conservative neighbourhoods of Ankara or İstanbul, or that they would never be willing to live in a society which restricts their lifestyles and choices. However, the same respondents narrated that in Berlin their comfort zone is Neukölln or Kreuzberg where the main portion of the Berlin Turkish 
population and similar regional backgrounds exist. To be more specific, while the New Wave felt suffocation of socio-political restrictions in Turkey and matched this with a vague definition of other, there is a shift in their perceptions towards that other lifestyle. The urban fabric of Neukölln and Kreuzberg is highly similar to districts of Keçiören, Sincan, Ümraniye, Fatih (areas which are unfavorable places in Turkey for those of the New Wave); certainly not similar to Kadıköy, Çayyolu or Nișantașı. The New Wave prefers to be in the most European style places in Turkey, and, yet, chooses the most orientalist localities as their comfort zone in Berlin. An interviewee, similar to many others, said that, "Tiergarten, Charlottenburg... Such areas are also nice, but I feel more comfortable in Neukölln or Kreuzberg." while another also stated that "Neukölln is the middle east of Berlin. But it is the place I feel most comfortable. There are always gentle people around." As it can be seen from the words of interviewees, the New Wave is not unaware of the social environment of Neukölln or Kreuzberg, just as they are not unaware of the socio-spatial conjuncture of Turkey. Therefore, this perceptional shift is not a delusion. Nevertheless, it is also impossible to say that it is certainly a conscious shift.

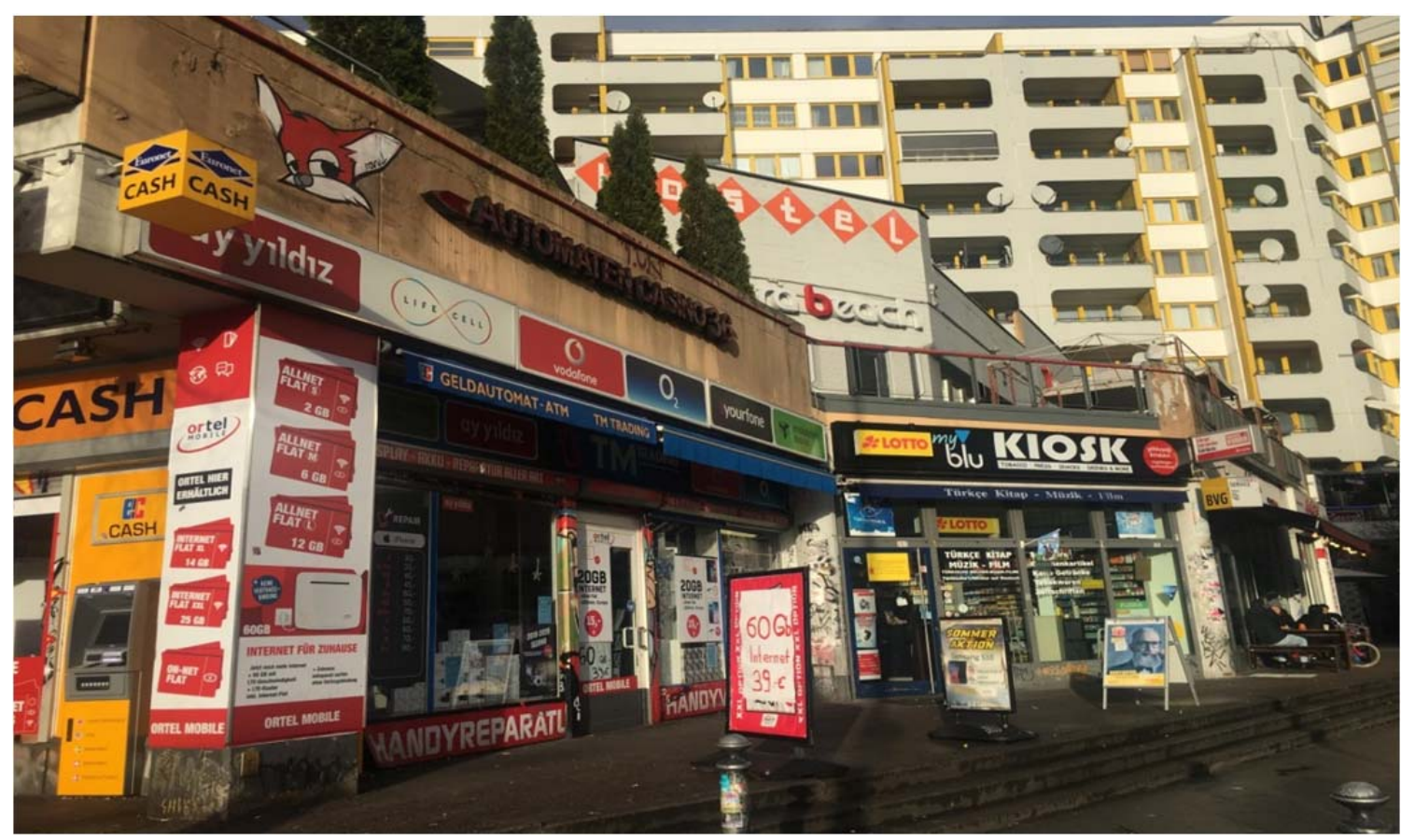

Figure 5. Shops with Turkish labels in Kreuzberg/Kottbusser Tor (December, 2019)

By looking to the public space use of the New Wave in Berlin, it was revealed that what the New Wave desires is not to be isolated and free from differences. On the other hand, they are certainly open to differences as they also have differences within and as they are willing to live with all diversities. Their unwillingness to interact with others is not because of a delusional hatred towards conservative or religious people. They only do not want to live under the control and domination of others. And the notion of other is surely a restricting, discriminative perspective in the big picture, not individuals. And this feeling of contradiction, struggle and sometimes even hatred gradually disappeared 
after the New Wave started to live in Berlin. Berlin provided places of escape and it also provided the sense of security that no government can play a dominant role in their daily lives. As government interventionism was removed from the scene, the strict line between us and them began to disappear. And later, this is reflected to public spaces like Neukölln or Kreuzberg, in which radically different lifestyles can coexist. As for the notion of security, once again, Berlin is mentioned as a 'city of freedom' for all respondents, except two. Especially when compared to İstanbul and Ankara, the feeling of security, freedom, and the manifestation of identities, interviewees found there to be prominent differences between Berlin and the other two cities. Since all respondents believe that Berlin is a place of co-existence for all identities and lifestyles, they usually argued that security and freedom come with the acceptance of whoever they are. A queer interviewee clearly expressed this as, "There is a place for everyone here and this is why I have never felt as an outcast or stranger in Berlin. And also, this is why I don't think about changing myself according to different places in the city. I am who I am and I am safe like this." The idea of being recognized brings the feeling of security in public space. Moreover, the character of public space is conceived by interviewees accordingly.

\section{Conclusion}

To turn back to the introduction, Turkey experiences a great deal of segregation which paves the way for tension, hatred, and violence in public space. A young, high-skilled, educated and now migrated group told their experiences of public life comparatively. Among Ankara, İstanbul and Berlin, it is shown that the main concerns are about feeling safe, feeling free and having inhabitable public spaces without the fear of being an outcast or controlled. Moreover, in terms of public space use, it is demonstrated that the New Wave is highly interested in open public areas where they can socialize. In light of all these concerns, all three cities were analysed. First and foremost, the issue on public space is about feeling familiar with and as an inhabitant of a district. In Ankara, Çankaya and Çayyolu districts are described as the most liveable with their characteristics of being educated and secular. In İstanbul, these days, Kadıköy appears to be the district of choice to be free and happy, after the disappointment felt by the New Wave in Beyoğlu, including İstiklal and Taksim. The second important concern was about the feeling of security, which can be defined as the safety of one's life, the guarantee of one's rights and liberties and freedom from any kind of physical or psychological harm in general; but, it can also be multiplied within other contexts as well. Security can also go along with familiarity and trust. A city in which people feel the most secure is probably be a place they know well, or at least a place they have familiarity with. Especially, when crime is taken into consideration; regardless of actual crime rates, many people will have the tendency to feel safer in the localities they know best. However, the dimension of gender exceeds the notion of familiarity and in some cases it is shown that being familiar with a public space does not necessarily mean that a woman will feel safe there as is, or this may change depending on her clothing. Finally, a significant shift is analysed in the last section. The perceptional shift that emerged with the migration of the New Wave to Berlin. This shift in perception includes tolerance and a sense of unity with the others, which previously had appeared to be an undesirable group to live with. This shift explains that the desire of the New Wave is neither to 
escape the people of Turkey, nor to develop a hatred towards them. Their unwillingness to share commons in public space with that non-specific other comes from the oppression and restriction they have faced in the last years. This is not to say that this is the only cause for the prominence ofsocial segregation in Turkey. That would be a naive analysis. It is rather only an offer to reconsider how public space plays an important role in unity and commons and how significant it is to use public space for coexistence rather than hatred. The perceptional shift of the New Wave after migrating to Berlin has demonstrated this very well.

\section{References}

Arendt, H. (1958/I 998). The Human Condition. (2nd ed.). The University of Chicago Press.

Aydın, Y. (2016). The Germany-Turkey migration corridor: Refitting policies for a transnational age. Washington DC: Migration Policy Institute. I-25.

Bodnar, J. (20I5). "Reclaiming public space”. Urban Studies, 52(12), 2090-2104.

Chaloff, J. \& Lemaitre, G. (2009). Managing Highly-Skilled Labour Migration: A Comparative Analysis of Migration Policies and Challenges in OECD Countries. OECD Social, Employment and Migration Working Papers, No. 79, OECD Publishing, Paris.

Ergun, A., \& Kulkul, C. (2018). Defining semi-public space: a case study in the gated communities of Yașamkent, Ankara. Turkish Studies, 20(5), 776-793.

Habermas, J. (1989). The Structural Transformation of the Public Sphere: An Inquiry into a Category of Bourgeois Society. Massachusetts Institute of Technology.

Jacobs, J. (1961). The Death and Life of Great American Cities. New York: Random House.

Kara, G., \& Yörükoğlu, C. (20I7). “Almanya’da Yașayan Yüksek Nitelikli Türk Göçmenler-Beyin Göçünün Yeterince Farkında Mıyız?", İktisat ve Toplum, 80, 3 I-42.

Kuymulu, M. B. (2013). Reclaiming the right to the city: Reflections on the urban uprisings in Turkey. City, 17(3), 274-278.

Okumuș, M. O. (2019). How Berlin Attracts the Turkish "New Wave”: Comparison of Economic and Socio Cultural Pull Factors for Highly Skilled Immigrants, (unpublished master's thesis), Hochschule für Wirtschaft und Recht Berlin: Political Economy of European Integration.

Örs, İ. R. (20I4). Genie in the bottle: Gezi Park, Taksim Square, and the realignment of democracy and space in Turkey. Philosophy \& Social Criticism, 40(4-5), 489-498.

Qian, J. (2018). Re-visioning the Public in Post-reform Urban China Poetics and Politics in Guangzhou.

Sennett, R. (20I3). Kamusal Insanın Çöküșü. Yılmaz, A. \& Durak, S. (Trans.). The Fall of Public Man. Ayrıntı. 
Interview Partners List

\begin{tabular}{|c|c|c|c|c|c|}
\hline & AGE & $\begin{array}{l}\text { CURRENT EDUCATION } \\
\text { LEVEL }\end{array}$ & $\begin{array}{l}\text { OCCUPATIONI } \\
\text { AREA }\end{array}$ & HOME COUNTRYICITY & $\begin{array}{l}\text { YEARS IN } \\
\text { BERLIN }\end{array}$ \\
\hline I. & 27 & UNDERGRADUATE & ARCHITECTURE & İSTANBUL & 9 \\
\hline 2. & 24 & GRADUATE & $\begin{array}{l}\text { INTERNATIONAL } \\
\text { RELATIONS }\end{array}$ & ANKARA & 3 MONTHS \\
\hline 3. & 29 & GRADUATE & NEUROSCIENCES & İSTANBUL & 6 \\
\hline 4. & 25 & GRADUATE & SOCIAL SCIENCES & ANKARA & I \\
\hline 5. & 24 & GRADUATE & MEDIA & İSTANBUL & I \\
\hline 6. & 24 & GRADUATE & $\begin{array}{l}\text { INDUSTRIAL } \\
\text { ENGINEERING }\end{array}$ & İSTANBUL & 2 \\
\hline 7. & 28 & GRADUATE & $\begin{array}{l}\text { INTERNATIONAL } \\
\text { ECONOMY }\end{array}$ & İSTANBUL & I \\
\hline 8. & 25 & UNDERGRADUATE & JOURNALISM & İSTANBUL & 2 \\
\hline 9. & 26 & GRADUATE & $\begin{array}{l}\text { INTERNATIONAL } \\
\text { RELATION }\end{array}$ & ANKARA & I \\
\hline 10. & 26 & GRADUATE & SOCIOLOGY & İSTANBUL & I \\
\hline II. & 24 & GRADUATE & $\begin{array}{l}\text { ENGLISH LANGUAGE } \\
\text { AND LITERATURE }\end{array}$ & ANKARA & 6 MONTHS \\
\hline 12. & 26 & GRADUATE & ECONOMY & İSTANBUL & 1 \\
\hline 13. & 28 & UNDERGRADUATE & $\begin{array}{l}\text { SOFTWARE } \\
\text { DEVELOPMENT }\end{array}$ & ANKARA & 9 MONTHS \\
\hline 14. & 26 & GRADUATE & POLITICAL SCIENCES & ANKARA & 3 \\
\hline 15. & 30 & GRADUATE & DESIGNER & İSTANBUL & 6 \\
\hline 16. & 28 & GRADUATE & POLITICAL SCIENCES & ANKARA & 3 \\
\hline 17. & 25 & UNDERGRADUATE & GRAPHIC DESIGN & İSTANBUL & 3 \\
\hline 18. & 26 & GRADUATE & POLITICAL SCIENCES & ANKARA & 2 \\
\hline 19. & 27 & UNDERGRADUATE & LAW & İSTANBUL & 7 MONTHS \\
\hline 20. & 30 & GRADUATE & SOCIOLOGY & İSTANBUL & 4 \\
\hline 21. & 29 & GRADUATE & $\begin{array}{l}\text { SOFTWARE } \\
\text { DEVELOPMENT }\end{array}$ & İSTANBUL & 3 MONTHS \\
\hline 22. & 25 & UNDERGRADUATE & $\begin{array}{l}\text { SOFTWARE } \\
\text { DEVELOPMENT }\end{array}$ & ANKARA & 6 MONTHS \\
\hline 23. & 24 & GRADUATE & MEDIA & İSTANBUL & 3 \\
\hline 24. & 26 & GRADUATE & $\begin{array}{l}\text { INTERNATIONAL } \\
\text { RELATIONS }\end{array}$ & ANKARA & 5 \\
\hline 25. & 28 & GRADUATE & FINE ARTS & İSTANBUL & I \\
\hline 26. & 25 & GRADUATE & ECONOMY & İSTANBUL & 2 \\
\hline 27. & 25 & GRADUATE & FINE ARTS & ANKARA & 2 \\
\hline 28. & 27 & UNDERGRADUATE & ARCHITECTURE & ANKARA & 2 \\
\hline 29. & 29 & UNDERGRADUATE & $\begin{array}{l}\text { SOFTWARE } \\
\text { DEVELOPMENT }\end{array}$ & ANKARA & I \\
\hline 30. & 26 & GRADUATE & JOURNALISM & İSTANBUL & 3 \\
\hline
\end{tabular}




\section{Notes}

' Retrieved from http://subjektif.org/gezi-parki-bildirileri/\#Anonim_Bildiri-18 on 26.06 .2018

${ }^{2}$ Retrieved from https://www.haberler.com/icki-nedeniyle-saldiriya-ugrayan-dukkani-koreli-8539478haberi/ Translated to English by the author.

${ }^{3}$ For further analysis, see Örs, İ. R. (2014) and Kuymulu, M. B. (2013).

${ }^{4}$ In 20I2, the then PM Erdogan stated that abortion is murder. In following years, this topic was highly debated and even though it was not made illegal, a great number of hospitals and private practices, and doctors have refused to perform abortions since. For more information see

https://www.ntv.com.tr/turkiye/erdogan-kurtaj-cinayettir,VgwTijiEyEuq-9Qcqqy6Ag?_ref=infinite and http://www.milliyet.com.tr/yasa-yok-ama-kurtaj-yasak/gundem/detay/l838845/default.htm (Retreived on November, 2018)

${ }^{5}$ In 2013, a hot debate occurred after Ö. T. Innançer stated that it is not aesthetically pleasing and that it is inappropriate for a pregnant woman to be visible in public after 6-7 months of her pregnancy. This statement was strongly criticized and protested not only by feminist groups and women organizations, but also by a great number of people. The whole statement can be found on https://www.haberturk.com/polemik/haber/86352I-hamile-kadinin-sokakta-gezmesi-uygun-degildir (Retrieved on November, 2018)

${ }^{6}$ The prime minister at the time, Erdogan asserted that it was their wish to rear religious youth, 2012. Retrieved from https://nationalpost.com/news/turkey-pm-recep-tayyip-erdogan-sparks-furor-by-saying-hewants-to-raise-a-religious-youth on 18.10 .2018 
7 The manifestation of Gezi Park protests above explicitly reveals this.

${ }^{8}$ Frank-Jürgen Weise, the chair of the German Federal Agency for Employment, in 20II, stated that Germany needs two million qualified immigrants. Retrieved from https://www.dw.com/tr/iki-milyonnitelikli-göçmene-ihtiyaç-var/a-I 5076239 (in Turkish). In 2012, Germany has also observed Blaue Karte EU which enables qualified workers to get a permanent residence permit or a work permit.

${ }^{9}$ For more information about the pull factors of Berlin for highly skilled young individuals, see, $M$. Oğuzhan Okumuș (2019) How Berlin Attracts the Turkish "New Wave”: Comparison of Economic and Socio Cultural Pull Factors for Highly Skilled Immigrants, (unpublished master's thesis)

${ }^{10}$ All pictures are taken by the author.

"For more information on spatial segregation in these neighborhoods, see Ayça Ergun \& Ceren Kulkul (2018): "Defining semi-public space: A case study in the gated communities of Yașamkent, Ankara", Turkish Studies.

${ }^{12}$ The second and third highest educated districts of Turkey are Kadıköy and Beșiktaș, respectively, in İstanbul. For more information about the research and statistics, see the website:

http://www.cumhuriyet.com.tr/haber/turkiye/874485/Turkiye_nin_en_egitimli_ilceleri_belli_oldu._ilk_uc sirada CHP li ilceler var.html

${ }_{13}$ http://www.greatlistanbul.com/besiktas.html

${ }_{14}^{14}$ Many respondents stated that they prefer certain localities and did not prefer others, mostly due to their inhabitants' world views and mentalities. 